\title{
DEVELOPMENT OF PRACTICE LEARNING MEDIA BASED ON PROGRAMMABLE LOGIC CONTROLLER
}

\author{
Md. Masudul Haque ${ }^{1}$ and Yaya Jakaria ${ }^{2}$ \\ ${ }^{1}$ National University-Bangladesh, ${ }^{1}$ Department of Survey of Bangladesh, Bangladesh; ${ }^{2}$ Directorate of Vocational High \\ Schools, Directorate General of Vocational Education, Ministry of Education and Culture, Indonesia \\ E-mail: masudul1002@gmail.com
}

\begin{abstract}
The objectives of the study were (1) to produce PLC-based Electrical Machine Practice learning media (2) to determine the performance of PLC-based Electrical Machine Practice learning media products and (3) to determine the feasibility level of PLC-based Electrical Machine Practice learning media products. This study was Research and Development which refers to the ADDIE model according to Branch. The stages in this study include analysis, design, development, implementation, and evaluation. Data collection methods used in this study were interviews, observations, and questionnaires. The instruments used in the study were the observation sheet and questionnaires. The results of this study indicated: (1) the product of learning media for Electrical Machine Practice based on PLC Schneider SR2B201FU; (2) the product of PLC-based Electrical Machine Practice learning media has good performance; (3) the product of PLC-based Electrical Machine Practice learning media has eligibility in the very feasible category to be used in learning, which is supported by the acquisition of a consecutive score of $3.65 ; 3.58$ and 3.58 on a 4.0 scale according to the validation of material experts, media experts, and students.
\end{abstract}

Keywords: electrical machine practice, learning media, programmable logic controllers

\section{INTRODUCTION}

The Electrical Machine Practice course has an important role because this course underlies courses on the Industrial Control concentration and the Industrial Electricity concentration in the following semester. The Electrical Machine Practice also supports the Industrial Practice course, besides that, through this course, it is expected that students will get provisions for the Electrical Machine Practice skills needed in industrial employment. Electrical machine practice is also required for vocational school teachers who will educate their students to enter the industrial world.

In the implementation of the Electrical Machine Practice lecture in the last five years, it is still not optimal. This is indicated by a statement from the course supervisor that the results of individual practice exams do not pass an average of $35 \%$ of each class and must do a repetition of exams or remedial to pass with a minimum grade of $B$. In addition, students who get the predicate $\mathrm{A}$ average score, only $10 \%$ of all students take Electrical Machinery Practice lectures. The reasons include the limitations of the type, quantity, and quality of the Electrical Machine Practice equipment in the Electrical Machinery Laboratories.

The existing Electrical Machine Practice Equipment in the laboratory has poor quality. Currently, in each class, the number of students participating in the practice is increasing, namely, an average of 20 people, which causes the Electrical Machine Practice to take place in large groups. This causes the Electric Machine Practice to run less effectively. In addition, the topics that are 
practiced in the Electrical Machinery Practice course are also limited, namely the practice of DC motors, DC generators, wound rotor 3phase AC electric motors, cage-rotor 3-phase $\mathrm{AC}$ electric motors, synchronous generators, and synchronous motors and transformers. Other topics such as starting DC motors and $\mathrm{AC}$ motors, braking $\mathrm{DC}$ motors and $\mathrm{AC}$ motors, regulating the rotation of $\mathrm{DC}$ motors and $\mathrm{AC}$ motors have never been practiced. To overcome this problem, it is necessary to develop practical tools in the form of learning media that can be used to practice some topics that have never been practiced.

The learning media developed must have a control base that is currently widely used in industry, so that in this study the control base for Programmable Logic Controller (PLC) is used. PLC is sophisticated control technologies utilized by many industries [1]-[5]. The technological change of the last few years has led to a change in the control system, and the control system is now automated, in which the development of microelectronic components can ultimately produce a system that can replace the functions of tens or even hundreds of electromechanical relays with just one programmable logic controller micro controller chip [6]. Programmable logic controller (PLC) is a microprocessor used to automate industry processes such as controlling and controlling a factory's engine [7]. Sophisticated control technologies, such as Programmable Logic Controller (PLC), are utilized by many industries.

Through this study, it was obtained Electrical Machine Practice learning media that can be used to add to the topic of learning practice of electric machines for one semester, thus making practical activities more effective. The product produced by this study is in the form of PLC-based Electrical Machine Practice learning media. This learning media for the Practice of Electrical Machines can be used for practical topics including the practice of starting DC motors and $\mathrm{AC}$ motors, regulating $\mathrm{DC}$ motor rotation and $\mathrm{AC}$ motors, and braking $\mathrm{DC}$ motors and 3-phase induction motors. The electric motor used is a DC motor with specifications, 220Vdc, $1.2 \mathrm{KW}$, and $1400 \mathrm{rpm}$, a 1-phase AC motor with $220 \mathrm{Vac}, 40 \mathrm{~W}$ specifications, and a 3-phase $\mathrm{AC}$ motor with specifications, 220/380 Vac, $0.75 \mathrm{KW}$, and $1450 \mathrm{rpm}$.

This learning medium requires a PLC that is easy to use and has many input outputs, so this learning media uses the Zelio SR2B201FU PLC series which has twelve inputs and eight outputs. The PLC can also use a 1-phase AC source with a voltage of 100 volt to 220volt. By considering the place, to obtain a learning media in the form of trapezium which has a height of $100 \mathrm{~cm}$, width $30 \mathrm{~cm}$, and length of $100 \mathrm{~cm}$. The framework used is in the form of aluminum and iron plate, and for display components using acrylic so that the learning media is sturdy.

\section{METHOD}

This study was research and development. Some of the previous studies [8]-[10] have developed this model for several cases such as LC $5 \mathrm{E}$, improvement of the learning process, and practical learning in vocational high school. However, the research and development model used in this study refers to the ADDIE model according to 
Branch [11]. The ADDIE [12] model has a flowchart as shown in Figure 1.

The analysis stage aims to determine the potential or existing problems. The analysis was carried out by analyzing environmental conditions, conditions for the continuity of the learning process, conditions of graduation level, and student understanding. After the analysis is carried out, it will produce solutions to existing problems, which will then be consulted with the learning expert team to find out whether these solutions can solve existing problems.

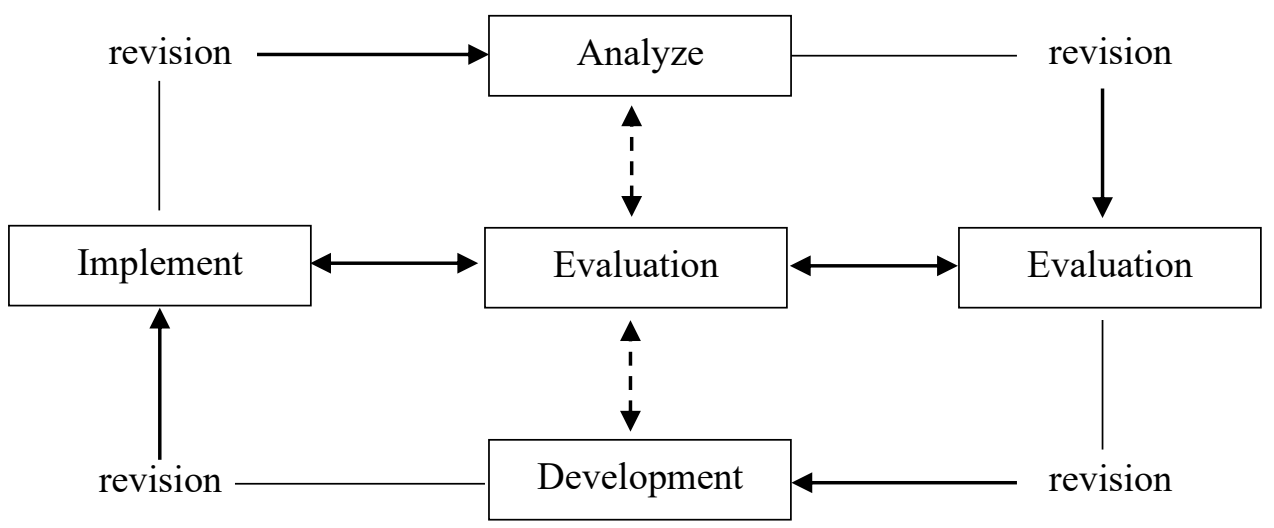

Figure 1. Diagram of the ADDIE Model Development Procedure

In design activities, the design is carried out based on the results of the needs analysis. In this study, the results of the needs analysis were in the form of instructional media, so that at this stage the researcher would determine the elements needed in the learning media, referring to [8]. At this stage, the researcher will also design a lab sheet and guidebook as a complement to the learning media. The advantage of the developed learning media is the use of PLC as a control component. The existing learning media in the existing electric machine laboratory does not have a control unit. In addition, the learning media developed can be used for learning topics that have never been conveyed, such as 3-phase AC electric motor rotation control. In addition to learning media, lab sheets, and manuals, researchers will also design research instruments that will be used to assess and validate learning media products that will be used using software assistance [13]. The arrangement of the instrument will pay attention to the elements of media assessment [14], namely the aspects of feasibility and suitability. The development stage is the stage of realizing the designs that have been made in the previous stage, namely producing learning media, lab sheets, manuals, and research instruments [15], [16]. The development of Electrical Machine Practice learning media includes the manufacture of mechanical and electrical structures. The manufacture of the mechanical structure of the Electrical Machine Practice learning media is conducted by assembling each of the mechanical components into a single unified system that is interrelated with one another and can function as planned. Likewise, in the 
manufacture of an electrical system for learning media of Electrical Machine Practice, it is carried out by connecting electrical components into one electrical system that works following the planned electrical system functions.

The next step is testing the performance of the Electrical Machine Practice learning media. After testing the performance of learning media to produce a good performance in learning media, the next step is the validation of learning media products by material experts and media experts. Validation is carried out to assess the appropriateness and suitability of the trainer kit to be used as learning media in the Electrical Mechanical Practice course. In the implementation stage, lecturers use learning media products and lab sheets in learning. The researcher observes the ongoing learning process and records important events that can be used as input for the improvement of learning media. Then the evaluation of learning media is carried out by students who have practiced using learning media developed using questionnaires. Whereas in the final stage (evaluation), it is carried out in consultation with a team of experts, lecturers who teach courses, and research subjects. Evaluation is carried out at each stage of ADDIE [12], [17].

\section{RESULTS AND DISCUSSION}

According to the ADDIE development model [12], the initial product development stage includes three stages, namely, Analysis, Design, and Development. The following are the results of each of these steps. The data at the analysis stage came from observations made by researchers. Then the results of these observations are discussed with the lecturer who teaches the Electrical Machinery Practice course and a team of experts.

Observation data are in the form of needs analysis data for the development of learning media. Qualitatively, the data from the analysis results can be revealed that what is needed in the learning of Electrical Machine Practice is the Electrical Machine Practice learning media that can be used to carry out the Electrical Machine Practice material that has not been practiced so far. Practical materials for electric machines that cannot be put into practice include the practice of starting $\mathrm{DC}$ motors and $\mathrm{AC}$ motors, braking $\mathrm{DC}$ motors and $\mathrm{AC}$ motors, and controlling $\mathrm{AC}$ motor rotation.

Furthermore, further analysis is carried out [17] regarding the need for components to be used to develop learning media for Electrical Machine Practice which is supported by a lab sheet for the topic of Electrical Machine Practice that cannot be implemented. The media expert added that the PLC series used for learning media was the Zelio PLC SR2B201FU series which had many inputs and outputs to increase the flexibility of learning media. Table 1 below is the result of the analysis of the needs of the components of the Electrical Machine Practice learning media.

The results of the laboratory need analysis are the results of suggestions from lecturers who teach the subjects, which indicate that 6 topics of electrical machine practice need to be developed, namely: (a) Starting a DC Motor; (b) Dynamic DC Motor Braking; (c) Control of 1-Phase AC Motor Rotation Speed Variation; (d) Starting 3 
Phase AC Motor Using an Forward Reverse 3 Phase AC Motor; (f) 3Autotransformator; (e) Control of Automatic phase AC motor braking by DC injection.

\begin{tabular}{|c|c|c|c|}
\hline No & Name & Specification & Total \\
\hline 1 & Programmable Logic Controller (PLC) & $\begin{array}{l}\text { Schneider SR2B201FU } \\
\text { Compact Smart Relai Zelio Logic } 20 \text { I/O } 100 \text { - } 240 \\
\text { Volt AC }\end{array}$ & 1 Unit \\
\hline 2 & Miniature Circuit Breaker (MCB) 1 Phase & Schneider 1 Phase $10 \mathrm{~A}$ & 1Uni \\
\hline 3 & Miniature Circuit Breaker (MCB) 3 Phase & Schneider 3 Phase 32A & 1 Unit \\
\hline 4 & Magnetic Contactor & Mitsubishi S-N20 & 4 Units \\
\hline 5 & Thermal Overload Relay & Mitsubishi TH-N12 2A-3A & 2 Units \\
\hline 6 & Socket Banana & Red 25, Black 25, Blue 15, Green 70, Yellow 15 & 150 Units \\
\hline 7 & Pilot light & $\begin{array}{l}\text { AD16 Red } 5 \\
\text { AD16 Light Green } 12 \\
\text { AD16 Yellow } 2\end{array}$ & 19 Units \\
\hline 8 & Push Button & R13-507 & 15 Units \\
\hline 9 & Body Trainer & Alumunium, $100 \times 45 \times 92 \mathrm{CM}$ & 1 Unit \\
\hline 10 & Acrylic & Dimension $0.3 \times 86 \times 94$ & 1 Unit \\
\hline
\end{tabular}

After conducting a needs analysis, the next step is to design the shape and appearance of the instructional media which is then consulted with a team of experts and lecturers. The advice from the expert team at this stage was the arrangement of the front view of the trainer kit to make it tidier and denser to suppress the size of the learning media being developed. The following is the design of the front view of the learning media, the learning media component, the form design of the learning media, and the design of the Lab sheet format plan.

The Development Stage is the stage of realizing the designs made in the previous stage. For the manufacture of Electrical Machine Practice learning media, it starts with the creation of the framework and acrylic cutting lesser which will be used as a learning media interface. After that, proceed with installing the learning media components and installing the Banana Plug
Female and the connecting cable between the banana plug and the components. Installation of components is carried out using the MCB Rail which is screwed and bolted to the learning media framework. For cable, installation is done using a cable skun thus it is easier and safer because it uses a rubber protector or cable seal. Figure 2 shows the interface design of learning media.

After the process of making learning media, an Electrical Machine Practice learning media product is obtained which is the result of initial product development. The product of Electrical Machine Practice learning media and several components of the learning media is presented in Figure 3. The next step is validation carried out by material experts on the trainer product, which is equipped with a Lab sheet. The results of the validation are in the form of values for the aspects presented in the questionnaire, which have the results presented in Table 2, Table 3 and Table 4. 


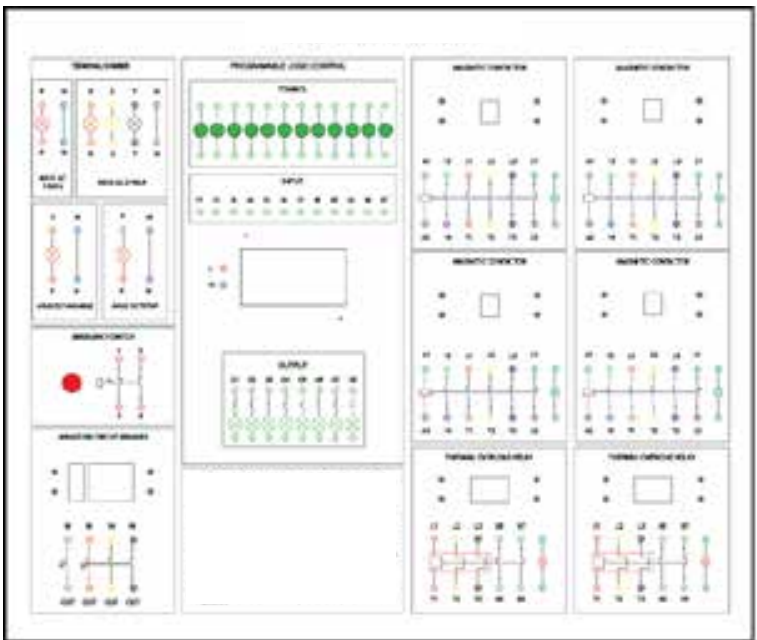

Figure 2. Interface Design of Learning Media

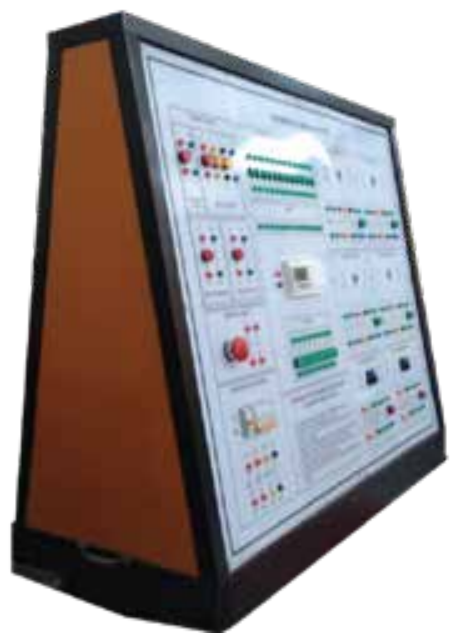

Figure 3. Results of the Electrical Machine Practice Trainer Kit Development

Table 2. Performance Test Results of the Components of the Electrical Machine Practice Learning Media

\begin{tabular}{|c|c|c|c|c|}
\hline \multirow[t]{2}{*}{ No } & \multirow{2}{*}{$\begin{array}{c}\text { Sections / } \\
\text { Blocks }\end{array}$} & \multirow{2}{*}{ Performance Description } & \multicolumn{2}{|c|}{ Function } \\
\hline & & & Yes & No \\
\hline 1. & $\begin{array}{l}\text { AC power } \\
\text { supply }\end{array}$ & Voltage: Phase-Neutral $=220$ Volt; Phases $=380$ Volts. & $\sqrt{ }$ & \\
\hline 2. & $\begin{array}{l}\text { DC power } \\
\text { supply }\end{array}$ & Voltage: 220 Volt DC. & $\sqrt{ }$ & \\
\hline 3. & PLC & Voltage: 0 - 220 Volt DC & $\sqrt{ }$ & \\
\hline 4. & Inputs I1 to I12 & 220 Volt AC power supply, On when supplied with power supply. & $\sqrt{ }$ & \\
\hline 5. & Output Q1 to Q8 & By running a simple ladder diagram I1 activates Q1 and so on. & $\sqrt{ }$ & \\
\hline 6. & $\begin{array}{l}\text { Output indicator } \\
\text { light (green) }\end{array}$ & $\begin{array}{l}\text { On, if power is being supplied to the PLC and Off, if power is not } \\
\text { being supplied to the PLC. }\end{array}$ & $\sqrt{ }$ & \\
\hline 7. & $\begin{array}{l}\text { TOR indicator } \\
\text { light (red) }\end{array}$ & $\begin{array}{l}\text { On, if there is an overload on the load and TOR trip and Off, if the } \\
\text { load is normal }\end{array}$ & $\sqrt{ }$ & \\
\hline 8. & $\begin{array}{l}\text { MC Indicator } \\
\text { Light (green) }\end{array}$ & $\begin{array}{l}\text { On, if the MC coil is energized and Off, if the MC coil is not } \\
\text { energized }\end{array}$ & $\sqrt{ }$ & \\
\hline 9. & $\begin{array}{l}\text { Source indicator } \\
\text { light }(\mathrm{m} / \mathrm{k} / \mathrm{k}))\end{array}$ & $\begin{array}{l}\text { On, if there is a source connected and Off, if the source is not } \\
\text { connected }\end{array}$ & $\sqrt{ }$ & \\
\hline 10. & Programming & $\begin{array}{l}\text { PLC can work under the programming after the program is } \\
\text { transferred from the computer to the PLC or after being programmed } \\
\text { directly in the PLC }\end{array}$ & $\sqrt{ }$ & \\
\hline 11. & Push-button & $\begin{array}{l}\text { If pressed then the contact is connected, if not pressed the contact is } \\
\text { open. }\end{array}$ & $\sqrt{ }$ & \\
\hline 12. & $\begin{array}{l}\text { Emergency } \\
\text { Switch }\end{array}$ & $\begin{array}{l}\text { NC Connects when normal conditions, NC disconnects when } \\
\text { squeezed, NO disconnects when normal conditions and NO closes } \\
\text { when squeezed }\end{array}$ & $\sqrt{ }$ & \\
\hline 13. & $\begin{array}{l}\text { Magnetic } \\
\text { Contactor }\end{array}$ & $\begin{array}{l}\text { If the coil has a working voltage, NO is closed and NC is open, if the } \\
\text { coil is not working voltage, NO is open and NC is closed. Primary } \\
\text { contact such as NO }\end{array}$ & $\sqrt{ }$ & \\
\hline The & vhole item $(100 \%)$ & & $\sqrt{ }$ & \\
\hline
\end{tabular}


Table 3. Results of the Performance Test for the Use of Electrical Machine Practice Learning Media for Several Practice

\begin{tabular}{llcc}
\hline \multicolumn{1}{c}{ No } & \multicolumn{1}{c}{ Topics } & Function & Yes \\
\hline 1. & Starting DC Motor & $\sqrt{ }$ \\
2. & Dynamic DC Motor Braking & $\sqrt{ }$ \\
3. & 1 Phase Induction Motor Speed Control & $\sqrt{ }$ \\
4. & Starting 3 phase induction motor using an autotransformer & $\sqrt{ }$ \\
5. & Control of 3 phase induction motor rotation & $\sqrt{ }$ \\
6. & 3 phase induction motor braking by DC injection & $\sqrt{ }$ \\
\hline
\end{tabular}

Table 4. The Calculation Results of Average Score and Categorization on the Validation of Material Experts

\begin{tabular}{ccccccc}
\hline \multirow{2}{*}{ No. } & \multirow{2}{*}{ Assessment Aspect } & \multicolumn{2}{c}{ Average score } & Maximum & Average & Category \\
\cline { 3 - 4 } & & Expert 1 & Expert 2 & score & & \\
\hline 1 & Quality of materials & 3.81 & 3.52 & 4 & 3.7 & Very good \\
2 & Usefulness & 3.87 & 3.44 & 4 & 3.6 & Very good \\
\hline \multicolumn{2}{r}{} & & & 4 & 3.65 & Very good \\
\hline
\end{tabular}

The material expert's validation of the Electrical Machine Practice learning media on the aspect of material quality has a mean value of 3.7 which is in the very feasible category and the usefulness aspect has a mean score of 3.6 which is also in the very feasible category.
Overall, the average value is 3.65 which is also in the very feasible category. Thus, according to the material expert, the product of the Electrical Machine Practice learning media has the feasibility of being in a very suitable category for use in learning.

Table 5. Results of the Calculation of Average Score and Categorization on the Validation of Media Experts

\begin{tabular}{ccccccc}
\hline \multirow{2}{*}{ No. } & Assessment Aspect & \multicolumn{2}{c}{ Expert score } & Maximum & Average & Category \\
\cline { 3 - 4 } & & 1 & 2 & & score & \\
\hline 1 & Media Design & 3.48 & 3.69 & 4 & 3.58 & Very good \\
2 & Operation & 3.43 & 3.29 & 4 & 3.36 & Very good \\
3 & Usefulness & 3.55 & 3.91 & 4 & 3.73 & Very good \\
\hline & Average Total Score & & 4 & 3.58 & Very good \\
\hline
\end{tabular}

The validation of media experts on the product in the aspects of design, operation, benefits is 3.58 ; 3.36 ; and 3.73 which are categorized as very feasible. Thus, according to media experts, the product of the Electrical Machine Practice learning media is eligible for the category very feasible for use in learning. Product Trial Results at the Implementation stage according to the ADDIE development model [12], namely the product trial stage is the Implementation stage. At this stage, the Electrical Machine Practice learning media product, which is equipped with a lab sheet, is tried out in the learning that is followed by students. In this study, the trial of the application of the Electrical Machine Practice learning media product in learning was attended by 50 students of the Electrical Engineering Education Study Program. The trials that were followed by these students were divided into several classes and different practice times.

In the evaluation stage, after students have finished practicing using the Electrical 
Machine Practice learning media equipped with a lab sheet, students are asked to provide an assessment of the Electric Machine Practice learning media product. The results of the assessment carried out by students of the Electrical Machine Practice learning media products equipped with a lab sheet are presented in Table 6 .

Table 6. Student Assessment Results of Electrical Machine Practice Learning Media Products

\begin{tabular}{lllll}
\hline \multicolumn{4}{c}{ Machine Practice Learning Media Products } \\
\hline No. & $\begin{array}{l}\text { Assessment } \\
\text { Aspect }\end{array}$ & $\begin{array}{l}\text { Maximal } \\
\text { Score }\end{array}$ & Average & Category \\
\hline 1 & $\begin{array}{l}\text { Material } \\
\text { Quality }\end{array}$ & 4 & 3.12 & $\begin{array}{l}\text { Very } \\
\text { good }\end{array}$ \\
2 & $\begin{array}{l}\text { Media } \\
\text { Quality } \\
\text { Benefit }\end{array}$ & 4 & 3.14 & $\begin{array}{l}\text { Very } \\
\text { good } \\
\text { Very } \\
\text { good }\end{array}$ \\
\hline \multirow{3}{*}{$\begin{array}{lllll}\text { Average } \\
\text { Total Score }\end{array}$} & 4 & 3.20 & 3.15 & $\begin{array}{l}\text { Very } \\
\text { good }\end{array}$ \\
\hline
\end{tabular}

Based on Table 6, it shows that the results of the student's assessment of the Electrical Machine Practice learning media products on the aspects of material quality, media quality, and benefits are $3.12 ; 3.14$; and 3.20 which is in the very feasible category. Thus, according to students, the product of the Electrical Machine Practice learning media has the feasibility of being a very suitable category for use in learning.

In the final stage, namely product revision is carried out based on the advice of material experts and media experts. Things that can be described include (1) Revision of Practice Safety: In occupational safety, it is recommended that sentences be changed to clear sentences. Furthermore, point number 7 is also added, namely "if there is a consultation with the lecturer" and point number 8 , namely "do not connect the motor source before the PLC program is working properly; (2) Adding the number of the image to the image, In the drawing in each lab sheet being developed, adding the number and caption of the image below the picture The addition of an image name aims to tell the meaning of the image, and so that users can more easily understand the meaning of the image displayed.

Furthermore, in the third revision, there is the addition of a series image, the addition of a series image meant by media experts and material experts is a series image that is under reality, or with pictures of learning media, electric motors, and other additional components. The addition of this picture aims to clarify the existing series on the lab sheet thus students can quickly understand the series; (4) Addition of Basic Material to PLC.

The fifth revision includes the addition of PLC material to the laboratory sheet suggested by material experts, so that students can use the Zelio PLC controller component in the learning media; (6) Addition of manual books for the use of instructional media, additional manuals are suggested by media experts. The book is useful to tell how to use the correct and safe Electrical Machine Practice learning media.

At the stage of the study, the final product in the discussion this time is the final result of product development, namely in the form of an Electrical Machine Practice learning media equipped with an Electrical Machine Practice lab sheet. To examine the final product of learning media, a SWOT analysis is used. SWOT analysis is an evaluation of products with a review of four aspects, namely strength, weakness, opportunity, and threat [18].

The strength of the final product from this development research is in the form of 
Electrical Machine Practice learning media equipped with a lab sheet. The strength of the Electrical Machine Practice learning media is the presence of PLC as the brain controlling various electric machine operations so that the Electrical Machine Practice learning media has high reliability and flexibility of use. The use of PLC as a control system can be used for all Electric Motor control circuits in all developed laboratories or control circuits that do not yet exist in the lab sheet.

Reliability on the PLC, namely the many relay control systems and when not changed through the program, the relay control system will not change as well and will remain as long as the PLC is still working normally. In addition, the use of PLC will also attract students' attention more than the use of ordinary relays, because students can be creative with the existing programming system in PLC.

While the weakness of this Electrical Machine Practice learning media is the lack of components to maximize the use of $\mathrm{I} / \mathrm{O}$ on PLCs. The Zelio PLC SR2B201FU series has 12 inputs and 8 outputs. In learning media, only 3 inputs are used per lab sheet, and only 3 outputs are used for each lab sheet, so the use of PLC input and output is not optimal. Opportunities that can be developed in the Electrical Machine Practice learning media are opportunities for further development, such as the addition of a multimeter to the learning media interface. Based on the data taken from students, some students suggest adding a Multimeter to the learning media so that the measurements carried out on the lab sheet become easier. In addition, with the use of PLC inputs and outputs that are still small for existing practical topics, it becomes material for further research to create other practical topics that can make optimal use of PLC input and output.

The threat that exists in the Electrical Machine Practice learning media is in making interfaces using acrylic-based materials, and to make writing on the interface printed using stickers. The use of stickers on acrylic tends to get dirty faster and is less durable than using acrylic engraves. This is because the use of stickers peels easily and over time the ink printed on the stickers will fade quickly.

\section{CONCLUSION}

The conclusions that can be drawn from this study include: (1) The product of PLCbased Electrical Machine Practice learning media has good performance. Each component or part of the learning media can work properly and according to its function. (2) The PLC-based Electrical Machine Practice learning media is feasible to be used.

\section{REFERENCES}

[1] E. Lukito, F. Arifin, and P. Walipranoto, "Development of Learning Media (Programmable Logic Controller) as a Case Study of Sorting Machine Applications on Electronics Engineering Education Study Program Faculty of Engineering Universitas Negeri Yogyakarta," Adv. Soc. Sci. Educ. Humanit. Res., vol. 440, 2019.

[2] Soeharto, Sukir, and A. S. J. Wardhana, "Performance of A Programmable Logic Controller Based Electrical Machine Trainer Kit," J. Phys. Conf. Ser., no. 1413 012011, 2019. 
[3] J. M. Sumilat, F. R. Seke, and J. Mantiri, "Simulation Method in Programmable Logic Controller," J. Educ. Method Technol., vol. 1, no. 2, pp. 67-76, 2018.

[4] A. Septian MN, "Penerapan Trainer Human Machine Interface (HMI) Berbasis CX-Designer Sebagai Media Pembelajaran Programmable Logic Controller (PLC)," J. Inform. Univ. Pamulang, vol. 3, no. 4, 2018.

[5] A. M. Mappalotteng, H. Nur, and F. Kanan, "The Development of Programmable Logic Controller Tutorial in the Form of IndustrialBased Learning Materials in Vocational High Schools," Res. Inven. Int. J. Emgineering Sci., vol. 5, no. 5, pp. 49-58, 2015.

[6] F. Pinnekamp, "Product Automation," in Springer Handbook of Automation, Berlin, Heidelberg: Springer, 2009, pp. 545-558.

[7] M. Ioannides, "Design and Implementation of PLC-based Monitoring Control System for Induction Motor," IEEE Trans. Energy Convers., vol. 15, no. 1, pp. 7-14, 2004.

[8] H. Zamtinah, "Peningkatan Hasil Belajar Mata Kuliah Instalasi Listrik Melalui Pendekatan Learning Cycle Five 'E' (LC 5 E),' J. Pendidik. Teknol. dan Kejuru., vol. 22, no. 2, 2014.

$\begin{array}{llr}\text { Tiwan, } & \text { "Penerapan } & \text { Modul } \\ \text { Pembelajaran } & \text { Bahan Teknik } & \text { sebagai } \\ \text { Upaya } & \text { Peningkatan } & \text { Proses }\end{array}$

Pembelajaran di Jurusan Pendidikan Teknik Mesin FT UNY," J. Pendidik. Teknol. dan Kejuru., vol. 19, no. 2, 2010.

[10] B. G. Purnomo and T. Sukardi, "Integration of Project-Based Entrepreneurship and Productive Practical Learning in Vocational High Schools," J. Pendidik. Teknol. dan Kejuru., vol. 25, no. 1, 2019.

[11] R. M. Branchs, Multimedia Based Instructional Design. USA: John Wiley \& Sonc, Inc, 2004.

[12] R. M. Branch, Instructional Design: The ADDIE Approach. Boston, MA: Springer US, 2009.

[13] T. P. Budi, SPSS 13.0 Terapan: Riset Statistik Parametrik. Yogyakarta: Andi Offset, 2006.

[14] S. Arikunto, Prosedur Penelitian: Suatu Pendekatan Praktik. Jakarta: Rineka Cipta, 2013.

[15] S. Thiagarajan, Instructional Development for Training Teachers of Exceptional Children. Washington DC: National Center for Improvement Educational System, 1974.

[16] Sugiyono, Metode Penelitian dan Pengembangan Research and Development. Bandung: Alfabeta, 2016.

[17] Sugiyono, Statistika Untuk Penelitian. Bandung: Alfabeta, 2006.

[18] F. N. D. Fatimah, Teknik Analisis SWOT. Jakarta: Quadrant, 2016. 